\title{
Epoch Relativism and Our Moral Hopelessness
}

\author{
Regina Rini York University, Toronto rarini@yorku.ca
}

\begin{abstract}
When we look back upon people in past societies, such as slaveholders and colonialists, we judge their actions to have been morally atrocious. Yet we should give some thought to how the future will judge us. Here I argue that future people are likely to regard our behavior as no better than that of the past. If these future people are to be believed, then we are morally hopeless; we have little chance of working out the moral truth for ourselves. I argue that we ought to resist this conclusion, and that our best means for doing so it to reject moral objectivity and accept instead a form of time-linked moral relativism.

This is a pre-copy-edited version of the essay. The final version appears, and can be cited, as: Regina Rini (2019). 'Epoch Relativism and Our Moral Hopelessness'. In Ethics Beyond the Limits: New Essays on Bernard Williams' Ethics and the Limits of Philosophy. Eds. Sophie Grace Chappell and Marcel van Ackeren. Routledge. Pp 168-187.
\end{abstract}

\section{Timely moral evaluation}

We often regard residents of the historical past as moral monsters. Enslavers, gleeful besiegers, royal torturers - all were engaged in behavior perfectly normal for their time, yet now clearly exposed as morally atrocious. Despite the familiarity of this thought, we rarely consider how we will appear once our own practices become encased in finitude and brought under history's moral microscope. The aim of this paper is to dwell on such disconcerting thoughts. I will argue that our distant descendants will likely look back on us as morally hopeless, blundering unwittingly through lives structured by normal practices that are in fact just as reprehensible as those of the cruel ancients. And this thought, I will claim, provides us with strong reason to endorse a form of time-linked moral relativism. If we are forced to choose (as I will argue) between accepting the utter condemnation of the future or relinquishing belief in moral objectivity, then we must choose the latter.

The spirit of my argument borrows much from Bernard Williams. Williams wrote the following about "queasy liberals" who are universalists (objectivists) about morality, yet find their substantive moral commitments challenged by reflection on the past:

[I]f liberalism is correct, it must apply to all those past people who were not liberals: they ought to have been liberals, and since they were not, they were bad, or stupid, or something on those lines. But - the queasy liberal feels, and to this extent he is right - these are foolish things to think about all 
those past people. So, he concludes, liberalism cannot be correct. That is the wrong conclusion; what he should do is give up the universalist belief. ${ }^{1}$

But where Williams' argument against moral objectivity looks backward, mine looks forward. Or, more precisely, my argument looks obliquely inward: at our own time, as reflected in the likely sentiments of our distant descendants. Just as the queasy liberal ought to abandon moral objectivity rather than liberalism, so ought we abandon objectivity rather than accept the condemnatory judgment of future people.

Formally, my argumentative strategy is a reductio. I will construct an argument - The Argument for Our Utter Moral Failure - conjoining belief in moral objectivity with two difficult-to-deny premises, leading to an unacceptable conclusion about our modern moral hopelessness. I will argue that we must reject this conclusion, yet can do so only by rejecting the moral objectivity premise.

Here is an overview of the absurdity-entailing argument:

\section{The Argument for Our Utter Moral Failure}

Objectivity: There are objective moral truths that hold across all time.

Progress: People in the distant future will make much better moral judgments than we do now. Retrospection: People in the distant future will look back on our behavior as utterly morally atrocious and ourselves as morally hopeless.

The Shameful Conclusion: It is almost certainly true that our present-day behavior is utterly morally atrocious and we are hopeless about how to improve it.

The rest of this chapter executes the reductio strategy. Section 2 justifies the formal validity of the Argument for Our Utter Moral Failure. Sections 3 and 4 consider attempts to reject Progress and/or Retrospection; I argue that rejecting either premise is implausible. Section 5 considers whether we ought to simply accept the Shameful Conclusion. I will argue that we should not. So, if the argument is valid, yet the conclusion unacceptable, and if we cannot plausibly reject Progress or Retrospection, then we ought to reject Objectivity. Section 6 explores what this means, drawing on Williams' famous idea of the 'relativism of distance' to support a view I call Epoch Relativism.

\footnotetext{
${ }^{1}$ Williams $(2005,67)$. I learned of this passage from Fricker (2010); in the final section I will return to considering Williams' own version of moral relativism, as well as Fricker's critique thereof.
} 


\section{The Argument for Our Utter Moral Failure is valid}

Suppose there are objective moral truths; it is true that some actions are objectively wrong, and others are objectively right. Some things are objectively permissible and others objectively obligatory. This is to say that rightness, wrongness, etc. are not relative to any particular moment in human history. An action that is objectively wrong is wrong now and was wrong two thousand years ago, and will be wrong four thousand years from now (if there are still any moral agents left). Further, it is wrong across historical cultures. What is objectively morally wrong is wrong for contemporary Koreans, twelfth century Aztecs, and thirty-second century English (if there are still any English left). Basically, Objectivity is a way of denying moral relativism. ${ }^{2}$

The idea of Objectivity is familiar enough, but what about the other premises? Progress says that people in the distant future will make much better moral judgments than we do now. They will think some things morally prohibited that we think normal or even morally required, and they will think other things morally required that we think optional or even prohibited. Nearly always, when they disagree with us, they are right and we are wrong.

Retrospection says that people in the future will look back on our present-day behavior as utterly morally atrocious and see us as morally hopeless. What do I mean by "utterly morally atrocious"? Think about chattel slavery. Think about the routine sale of 11 year old girls as unwilling brides. Think about the genocidal removal of indigenous peoples from North America and Australia. That's what I mean by utterly morally atrocious. ${ }^{3}$ What do I mean by "morally hopeless"? I mean: extremely ignorant about what morality requires, with no clear idea of how to improve our knowledge.

So, if there are objective moral truths that hold across time and place, and if the people in the future who believe that we are utterly morally atrocious and hopeless will make much better moral judgments than we do, then it follows that we are indeed very likely to be utterly morally atrocious and hopeless. The logic here is pedestrian: if two people are disagreeing about a truthapt matter, and there's no way in which the truth can be relative to each, and one is a much better judge in the relevant domain, then it is very likely that the better judge's belief is correct.

\footnotetext{
${ }^{2}$ It's worth keeping in mind that Objectivity is not the same as moral realism. Some people who are not moral realists nevertheless endorse something like Objectivity, because they think that e.g. reflection on the nature of rational agency militates towards a certain normative view, no matter who one happens to be (Korsgaard, 1996). Nor is rejecting Objectivity the same as endorsing moral antirealism. There are some naturalist realist theories that may be compatible with a form of relativism (Copp, 1995; Wong, 2006).

${ }^{3}$ Here I am deliberately using examples of things that very many people at the time took to be perfectly normal and morally permissible or even morally valuable. I am leaving to the side examples of acute breakdowns in social order, or of terrible behavior exhibited by some but not widely endorsed by all. So I am leaving to the side Hitler and le Comité de salut public, Tuol Sleng and the Jallianwala Bagh massacre. So you can be reassured that the Argument for Our Utter Moral Failure doesn't say that you are quite as morally atrocious as Hitler. You're only as morally atrocious as a typical $18^{\text {th }}$ century slaveholder.
} 
Note that the argument does not insist, as a matter of deductive certainty, that we must be atrocious and hopeless. That sort of claim would not follow logically. After all, Progress says only that future people will make much better moral judgments than we do. It doesn't say that they will make infallible moral judgments. Even if future people will make much better moral judgments than we do, and even if they will think we are utterly morally atrocious, their judgment about us might be a mistake. After all, Maryam Mirzakhani was surely much better with maths than I am, but even she probably made some arithmetical mistakes sometimes. So it is possible that future people will be mistaken about us.

But something's being possible does not make it likely. It is possible that I get some maths challenge right while Maryam Mirzakhani gets it wrong. Possible, just not very likely. If I am now looking at my answer to a maths challenge, and I see Mirzakhani's answer, and they are not the same, then I should conclude that it is extremely unlikely that I'm the one with the right answer.

Hence the Shameful Conclusion is probabilistic rather than certain - but that makes it barely any more comforting. It is vanishingly unlikely that our present-day moral behavior is not utterly morally atrocious. Believing that you are not utterly morally atrocious is at least as unreasonable as believing that you are better with maths than Maryam Mirzakhani.

\section{Rejecting Progress}

Progress: People in the distant future will make much better moral judgments than we do now.

If the Argument for Our Utter Moral Failure is hard to fault logically, perhaps we can invalidate one of its premises. First I will show why it is implausible to reject Progress.

One way to reject Progress is to assume that, after a certain near-enough point, there will be no future people. We will blow ourselves up, or be consumed by a novel plague, or deal our environment an irretrievably fatal wound. If there are no future people, then there will be no future people to have better moral judgments than we do (or, for that matter, to look back upon us as morally hopeless). So, technically, both Progress and Retrospection ought to be understood as conditional claims: 'if there are future people, then...' I leave this conditionality implicit in the official argument, rather than lard it with clauses that are not crucial to the main point. I think that the Shameful Conclusion follows just as readily from conditionalized versions of these premises. We do not escape the implications of predictable condemnation by our future moral 
superiors merely by ensuring that they are obliterated before they have the chance to pass judgment. ${ }^{4}$

Assuming, then, that there are future people, denying Progress would require taking a particular view about the quality of their moral judgments. Specifically, it would require denying that they are likely to benefit from the same historical process that we take ourselves to have benefited from. Most of us think that our moral judgments are much better than moral judgments of people in the distant past, and we tend to think this is not a matter of luck. It seems that our improvement upon historical moral judgments reflects a cumulative process of cultural learning. What Progress asserts is only that this cumulative process will continue, so that the quality of our distant descendant's moral judgments will improve still further. Rejecting Progress, then, means claiming that something will call a halt to this historical process of gradual improvement. How could that be?

One way to deny this historical route to Progress (and a natural complement for denying the Shameful Conclusion) would be to hold that our current moral judgments are already quite close to the final moral truth. We may not yet be perfect moral judges, but perhaps there is not much more room for improvement. If this is so, then Progress can't be right, because future people can be, at best, only a bit better moral judges than we are now.

Michael Huemer does not make exactly these claims, but in a recent paper he argues along suggestive lines. Huemer claims that we can observe a historical convergence upon liberal moral values, those values which recognize individual equality and dignity while opposing needless violence. ${ }^{5}$ He claims that "the change has been proceeding in the same direction for centuries, and the changes have affected nearly all societies across the globe. This is not a random walk; this calls out for an explanation" (Huemer 2016, 1999). His explanation is moral realism and the affirmation of liberal values as (approximating) objective moral truth. Convergence on a set of conceptually-linked beliefs suggests that they are truth-tracking. And, we might now add, that gives us reason to doubt the implication of Progress that we are still far from the truth. ${ }^{6}$

But there are two problems with Huemer's argument. The first is his claim that we have no other explanation for the apparent convergence on liberal values. Though he gives convincing reasons to set aside biological explanations, he almost entirely ignores technological and economic

\footnotetext{
${ }^{4}$ An interesting side note: in a way, acknowledging the conditionality of future humans slightly increases the plausibility of Retrospection. For if there are future humans, this will likely be because they survived some nuclear war or synthetic super-pathogen or environmental collapse. They will exist, but they will have seen horrors for which we are partly responsible and might have prevented. It will not be a surprise if these people look back upon us with something other than moral approbation.

${ }^{5}$ For related thoughts, see Pinker (2018).

${ }^{6}$ Technically, it might be possible to uphold Huemer's argument and accept Progress. Huemer is only claiming that we are converging upon the moral truth in modern liberalism; he might think that we still have very far to go. But this seems against the spirit of his argument, since it would suggest that liberalism is only a distant precursor to the truth, rather than something to positively affirm.
} 
explanations. He brushes aside the suggestion that the $19^{\text {th }}$ Century move away from an agrarian economy played much of a role in the abolition of slavery, because this

requires that we accept a great coincidence. For it is not just that slavery was abolished. It is that liberalism triumphed on many different issues over the past few centuries. Are we to believe it is coincidence that, at the same time that slavery was becoming economically inefficient, some other trend was leading women's suffrage to become more popular (perhaps women's suffrage also becomes more economically advantageous in industrial societies?), another trend was causing democracy to spread across the world, another was causing war to seem less glorious, another made torture seem less beneficial, and so on? (Huemer 2016, 1999).

Yet Huemer does not even consider whether all these developments might have a joint economic explanation. Here is a plausible historical hypothesis: the Industrial Revolution redistributed economic power from violence-wielding agrarian barons to a large middle class. Educating workers for the skills of manufacturing incidentally gave them intellectual independence, while the railroad and telegraph enabled new mass mobility and labor organization. If this is right, then we needn't assume any truth-tracking moral zeitgeist to account for the coordinated shift toward liberalism - we need only hypothesize that the economic consequences of $19^{\text {th }}$ Century technology empowered the emerging middle class to demand greater equality and less political violence. The industrially-strengthened democracies were then able to impose their values on much of the world following the Second World War, through Chapter VII of the United Nations Charter and the Bretton Woods financial system. The late $20^{\text {th }}$ Century 'convergence' then represents more an exercise of economic power than a logical consensus. This is, admittedly, a speculative explanation, but it has the explanatory advantage of carrying much less ontological baggage than Huemer's metaethical speculation. There is no need to invoke Hegel when we have Marx ready to hand.

The second problem with Huemer's argument is that it's not at all clear things are still moving in the direction he suggests. In Turkey and Russia, social-political attitudes have become steadily less liberal over the last 20 years. ${ }^{7}$ The growth of machine-learned surveillance has begun to enable new forms of authoritarian control in China. A wave of xenophobic, hateful populism has rolled through the politics of Poland, Hungary, Myanmar, and the United States. Huemer might claim that such things are a temporary switchback, that we'll soon return to the liberal path. Maybe. But our uncertainty points to a strange contingency in Huemer's argument. Suppose that the anti-liberal strands of the last decade are not a temporary divergence. Suppose that 200 years from now much of the world has been brought under the sway of soft authoritarianism, where a privileged few use technological dominance and cruel minority-baiting to addle the masses. They might then insist that history has been leading up to their values, that convergence on soft authoritarianism shows it to be the recommendation of moral reality. The fact that Huemer's

\footnotetext{
${ }^{7}$ See Gessen (2017) for a convincing and sobering argument that Russia's liberalization in the 1990s was a brief (and by now almost fully reversed) aberration from long historical trends.
} 
argument works just as well, no matter what ideology becomes dominant, suggests that it is not pointing toward anything Objective. For the same reason, it seems premature to take our liberal moment as approaching anything like the end of moral history.

These last few points may seem overly pessimistic; I appear to be suggesting that our modern liberal values are a contingent expression of economic power, with all the intellectual durability of a feather on the historical breeze. That is not how we prefer to think about such things. Indeed, it not normally how I think of such things, nor would I expect you to. Rather, in ordinary moral practice we tend to treat a faith in our own growing righteousness as a practical necessity (as opposed to a theoretical discovery). Reflecting on this fact, I'll now claim, gives us strong reason to insist on upholding Progress. I think that we are already practically committed to the following principle:

The Principle of Hope: If ours is at least a basically decent society, then there is reason to hope that we will impart at least a marginal improvement to the moral sensitivity of our children.

Acceptance of the Principle of Hope is implicit in virtually all our personal and political practice. We nurture in our children the empathic rudiments of moral concern and construct for them the scaffolding of autonomous deliberation, then we step aside and hope that they will make better use of it than we have done. Even those of us who do not personally raise children are invested in the provision of civic education. We care, and we hope, that we are contributing to a project of improving humanity's future by improving the next generation's moral sensitivity. It is not an accident that Martin Luther King Jr's celebrated Dream looks to the concrete future, not to a parallel world, in expressing the hope that his own children would "one day live in a nation where they will not be judged by the color of their skin but by the content of their character". Few social reformers expect to complete their ambitions within a single generation; their sacrifices make sense only with the hopeful assumption that they will have helped to improve the moral understanding of those who come after. ${ }^{8}$

I cannot prove that the next generation will make better moral judgments than we do. But I hope that they will. And many of the things I now do would not make sense if I rejected the Principle of Hope. I assume that the same is true for you. Yet if we hope that our children will be at least a little better than we are, and if we assume that this will make them able to improve their own children just a bit more, and if we then fix our sights to still more distant consequences, we will see that what we are really hoping for is that the line of moral sensitivity curves ever upward. The hope implicit in our moral practice is hope for Progress.

\footnotetext{
${ }^{8}$ The meaningfulness of many of our personal decisions may depend upon the intelligibility of this project (Scheffler, 2013). See also Moody-Adams (2017) for an argument that belief in ongoing moral progress is necessary for the psychological tenability of moral agency.
} 
You might wonder how what I've said here is supposed to be consistent with where I'm going if we are going to reject Objectivity, then how can we hope for Progress? Can we be relativists and still aim for moral improvement over time? But only the most ridiculous sort of moral relativism would deny that we can share moral norms with the generation immediately after ours - that is, with our own children. Relative moral truth, whatever that is, will consist of social practices that cross generational lines. So it is fully intelligible for relativists to see their own morality as the same thing as the morality of their children, and to hope that their children improve upon it by its own internal standards.

What is not intelligible for relativists is to insist that they share a morality with the people of a far distant future. Yet Progress remains intelligible for relativists, because it makes use of small, iterative changes. Each generation shares a moral system with its immediate predecessor and successor even as it brings about small positive changes by the lights of that system. It is the accumulation of those small changes that causes it to be true that distant-enough generations can no longer be evaluated by the same moral standards. Similarly: though it is a conceptual mistake to say that a chimpanzee is just a more effective mudfish, the two are connected by a long evolutionary chain in which stepwise comparative claims make perfect sense. ${ }^{9}$

I claim now that accepting Progress is the only option that makes sense of our own social practices. Rejecting it only seems plausible if we imagine ourselves as detached cosmic observers, holding back our bets on chancy prospects. But the lesson of the Principle of Hope is that we are not detached in this way - because we cannot hold back our bets. The intelligibility of our social practices assumes that we have already bet the house on Progress.

\section{Rejecting Retrospection}

Retrospection: People in the distant future will look back on our present-day behavior as utterly morally atrocious and ourselves as morally hopeless.

We ought not reject Progress; we ought not reject the idea that people in the far future will make much better moral judgments than we do now. Could we instead reject Retrospection? Retrospection says that people in the future will look back on our behavior as utterly morally atrocious and ourselves as morally hopeless. If we can plausibly deny that people in the future will look back on us in this way, then of course the Shameful Conclusion does not follow.

In fact, it does seem quite easy to deny Retrospection. To do so, we needn't go so far as positively predicting that future people will look back on us with approval, indifference, or even merely mild disapproval. All we have to say is that there is inadequate evidence for the assertion

\footnotetext{
${ }^{9}$ For related thoughts, see Michele Moody-Adams' claim that "moral progress is always local" (Moody-Adams 1999, 169). See also Catherine Wilson's (2010) argument for moral progress without moral realism.
} 
that future people will look back on us as morally atrocious. The burden of proof is on anyone who would assert Retrospection, and we might doubt that such a burden could be met for untestable claims about the attitudes of distant future people.

Here, then, is an attempt to meet that burden - to give a positive argument for Retrospection. The argument is a basic inductive sort. Most people, at most points in time, have looked back on others in the distant past as morally atrocious. The Book of Genesis finds the first humans guilty of the Original Sin, and deems it well-deserved that early generations were deliberately drowned by God. Looking back over the ancient customs of Rome's North African colony, Cicero wrote:

Who does not know of the custom of the Egyptians? Their minds are infected with degraded superstitions and they would sooner submit to any torment than injure an ibis or asp or cat or dog or crocodile, and even if they have unwittingly done anything of the kind there is no penalty from which they would recoil. ${ }^{10}$

Enlightenment European thinkers saw themselves as finding in reason a moral truth unavailable to their benighted ancestors. Their colonialist successors then brought this idea forcibly to other parts of the world, on an ostensibly civilizing mission to peoples seen as primitive moral throwbacks - "half devil and half child", in Kipling's words. These attitudes were not restricted to Europeans. The modernizing intellectual Fukuzawa Yukichi wrote this about his own early life, which he saw as representative of Japan before the Meiji Restoration:

I am wondering now if I was not like the "worm" in society - a kind of parasite feeding on the customs of the time - which had grown fat in the continued good season. This worm has always worshipped the lord of the clan, and had regarded him as a kind of superman. To this worm the lord's possessions were like the resources of nature - to be exploited and made use of by all men. I suppose a revolution in society was needed to rouse me from this illusion. The fall of the Tokugawa regime of three hundred years' standing gave me the cue, and for the first time I realized that my lord was as human as I, and that it was shameful to treat him as I had.

(Fukuzawa 1899/1996, 276)

We seem to always find it important to see what came before us as less good, or even as very bad. We want to believe that we benefit from and participate in the result of moral progress. Here I am not making a claim about what we ought to do, or what it is reasonable for us to do. I am making a psychological claim about what human beings tend to do. We tend to see our past, and especially our distant past, as a morally impoverished background against which the present day stands in comfortingly improved relief. Perhaps philosophers are particularly prone to the narration of history as moral progress, from Hobbes' account of growth from the mythical state of nature to Peter Singer's invocation of a historical 'expanding circle' of moral concern. This is

\footnotetext{
${ }^{10}$ Cicero, Tusculan Disputations. as translated and quoted in Isaac $(2004,357)$. Isaac points out that here Cicero uses the word pravitas, or "depravity, a term which Cicero uses frequently when he calls something not just mistaken, but utterly wrong".
} 
perhaps only the other side of the Principle of Hope; in order to see ourselves as capable of enabling a better future, we must believe we have already exceeded the past.

Of course there are exceptions to this pattern. At some times, in some places, people have seen in their contemporaries the signs of moral decadence, and rued their society's fall from some prior golden age. Enlightenment thinkers saw themselves as working to recover the lost glory of the classical era. Some contemporary American conservatives bemoan decline from the simpler times of the Founders. It is beside the point that what these people ache for is mostly fantasy rather than historical reality. Accurately or not, they look back upon some point in the past with moral praise, not scorn. Does this fact undermine the plausibility of Retrospection? Isn't it possible that future people will look back upon our time as a moral golden age?

The trouble with such halcyon thinking is that it is fickle. The spotlight of backward approbation swings through history as from a moving platform; each era finds its own golden age and the next overturns this verdict. Enlightenment Europeans rejected their medieval forebears and sang the glory of the classical era. Their Romantic successors then threw off the classical model and praised the raw honest experience of the medievals. Charles Nodier, a French Romantic, wrote this in 1820, only one generation after the completion of the Paris Panthéon:

The monuments upon which we impose with such scorn the name of Gothic and which we relegate to the construction of barbarians were neither so savage nor so barbarous... They are better than the Greek monuments in religious solemnity and in mysterious harmonies to the same degree that the noble beliefs of Christianity surpass the poetic theology of paganism. ${ }^{11}$

So perhaps some future people will see a moral golden age in our time. But this attitude will not last; a still later generation will reject their predecessors' valorization, and we will be consigned again to the undifferentiated benighted past. It is worth emphasizing this point: distant future people will see us, early $21^{\text {st }}$ century liberals, as shadily continuous with Weimar Germans and late $21^{\text {st }}$ century holdouts against rule by corporation. What seems to us now like firm generational markers will fade into irrelevance, and the richly varied strands of ideological struggle running through this century, the last, and the next, will be flattened and curated into one or two Capitalized Signifiers of an historically imaginary zeitgeist. Much as I just did to the Enlightenment and the Romantics, future people will limit our legacy to conveniently totalizing descriptors. If we are ever perceived as a moral golden age, it will be only through the blinkered beam of hagiography, and it will not last. When the spotlight of historical imagination rotates away to another golden age, we will be small and shadowed.

I am writing this way on purpose. It is important, in trying to imagine how the future will see us, that we keep in mind just how ordinarily insignificant we are. Because once we appreciate this fact, we can easily imagine how we will typically be seen from the future. The future will see us

\footnotetext{
${ }^{11}$ In Thorlby $(1966,157)$. It might be objected that this is an example of aesthetic rather than moral judgment. Yet it is hard to think of anyone with less patience for an aesthetic / moral distinction than the Romantics.
} 
just as we see the past. From our present, we look back on millennia of genocide, slavery, sexism and racism, colonialism, feudal oppression. We see generations of morally atrocious behavior, rolling along in waves, broken only on the shore of the very recent past when some (though not all) of these ancient evils were finally left behind. The present age is to us an historically sudden departure from the moral depths of the past - just as theirs was to the Victorians, and theirs to the Jacobins, and theirs to the Romans. From the future, we will be merely another point deep on the submerged floor leading to their emergence into light. Perhaps our line will be seen to curve upward, but it will still be far below the surface.

We should not reject Retrospection because, in this respect at least, we have every reason to expect the people of the future to be just like us.

\section{Accepting the Shameful Conclusion}

The Shameful Conclusion: It is almost certainly true that our present-day behavior is utterly morally atrocious and we are hopeless about how to improve it.

The Argument for Our Utter Moral Failure is valid and we should not reject Progress or Retrospection. We have two choices left: we may reject Objectivity or accept the Shameful Conclusion. I shall now argue that we should not do the latter.

This is an interesting juncture in my argument, because I suspect that some readers will want to accept the Shameful Conclusion - in fact they think they do accept it. They will say: just look at our world! We are indifferent to massive global poverty. We are selfishly destroying the environment. We torment and slaughter animals for our own gain. We are at best grudgingly accepting of racial and sexual equality, and we somehow still think it is a matter for debate whether queer people are fully equal citizens. If people in the future think that our present-day behavior is utterly morally atrocious, then they are right. ${ }^{12}$

It might seem that in rejecting the Shameful Conclusion, I must show these readers that they are mistaken, that our world is better than they think. But this is not what I will say. Rather, I wish to show that the implications of the Shameful Conclusion, understood in future historical context, are actually far worse than this. Not even the most fervent contemporary critic of our age should be happy with what the Shameful Conclusion really means. Indeed, I shall argue shortly, our standing for criticizing the present rests upon its rejection.

\footnotetext{
12 Evan Williams (2015) has recently argued exactly this: we are probably already amid an "ongoing moral catastrophe". Williams bases his conclusion not on the retrospection of future generations, but instead on induction from hopeless moral failures of the past and the combinatoric likelihood that at least one of our modern moral beliefs is disastrously flawed. He suggests that this possibility means we should focus on improving education, so that we can learn to recognize and rectify our ongoing failure. But if what I say below about moral hopelessness is correct, then it is not clear why Williams should expect that to work.
} 
Return again to how we view the past. When we look back at ordinary people living within horrible social systems, we see them not only as acting badly, but often as acting obliviously. They do not realize just how atrocious their behavior actually was. Often it takes an outsider even to notice the possibility for moral concern.

The British novelist Frances Trollope (mother of Anthony) found herself in slaveholding tidewater America in 1832. While visiting a relatively poor white family, she saved the life of an enslaved eight-year-old girl. The girl had eaten an arsenic-laced biscuit, carelessly left out as rat bait by one of the white family. Trollope quickly concocted a purging agent, and then held the girl as she shook and cried. There was a reaction from the onlookers, which she recounted as follows:

I observed a general titter among the white members of the family, while the black stood aloof, and looked stupefied. The youngest of the family, a little girl about the age of the young slave, after gazing at me for a few moments in utter astonishment, exclaimed, 'My! If Mrs Trollope has not taken her in her lap, and wiped her nasty mouth! Why I would not have touched her mouth for two hundred dollars!'13

The enslaved girl survived, but was in serious pain for some time. Hearing that she had still not recovered, Trollope returned:

I immediately went myself to enquire further, when another young lady of the family, the one by whose imprudence the accident had occurred, met my anxious enquiries with ill-suppressed mirth - told me that they had sent for the doctor - and then burst into uncontrollable laughter. The idea of really sympathizing in the suffering of a slave appeared to them as absurd as weeping over a calf that had been slaughtered by the butcher. ${ }^{14}$

The failure of these Virginia slaveholders was not simply in acting atrociously. It was in being unable to appreciate that their choices were morally significant at all. They saw slaveholding not as something to be morally justified, but as a mere background condition of life.

In other places, at other times, wrongdoers have gone further still. They did see their atrocious behavior as morally valenced, but they got it exactly backwards. They saw what they were doing as morally commendable, and they regarded moral criticism as foolish or destructive. This attitude was common to British imperialists, as dramatized in E.M. Forster's character Ronny Heaslop, a young administrator in the fading decades of the Raj. Told by his own mother that the

\footnotetext{
${ }^{13}$ Frances Trollope, Domestic Manners of the Americans, as excerpted in Breen (1996, 247-248).

${ }^{14} \mathrm{Ibid}$. It is notable Trollope did not support abolition of slavery. Later on the same page, she writes that emancipation "cannot, I conceive, be thought of, consistently with the safety of the country". She advocates instead legislation to reduce cruelty to slaves, so that they may be "rendered more profitably obedient" and as a result, "the negro population of the Union might cease to be a terror, and their situation no longer be a subject of indignation or of pity." Her audience for this writing was not slaveholding Americans, but Europeans. There were limitations to the moral sensitivity even of a foreign novelist.
} 
colonial authorities are treating Indians poorly, Heaslop exclaims, “Oh, how like a woman to worry over a side-issue!" He goes on:

We're out here to do justice and keep the peace. Them's my sentiments. India isn't a drawingroom. ... [W] hat do you and Adela want me to do? Go against my class, against all the people I respect and admire out here? Lose such power as I have for doing good in this country because my behavior isn't pleasant? You neither of you understand what work is, or you'd never talk such eyewash. It's morbidly sensitive to go on as Adela and you go. ... I'm out here to work, mind, to hold this wretched country by force. I'm not a missionary or a Labour Member or a vague sentimental sympathetic literary man. I'm just a servant of the Government; it's the profession you wanted me to choose myself, and that's that. We're not pleasant in India, and we don't intend to be pleasant. We've something more important to do. (Forster 1924, 51-52)

As Ronny Heaslop sees it, colonial rule is a force for justice. Complaints otherwise are the silly misunderstandings of women and sentimental literary men. Many atrocious social systems appear like this to those who live within them. Unjust arrangements are constructed (often without any agential intent) so as to obscure from their beneficiaries exactly what it is that they are really doing, to deprive the victims the ability to testify to injustice in these terms, and even to represent injustice as a commendable improvement upon earlier times. ${ }^{15}$

If this was true for the past, it must be true for the present. The full significance of the Shameful Conclusion is not that we are morally atrocious in ways we might already recognize. It is that we are atrocious in ways we do not and cannot recognize. Things we do right now that seem perfectly normal, perhaps not morally valenced at all or perhaps even morally good, are actually horrible things akin to slavery and colonialism. Or so future people will say of us.

You'll want to be given an example of this, of course. But of course I cannot give one. If I am right, then I am not in a position to know which of our current innocuous behaviors will be looked upon with horror. Even if I did somehow know, through some magical foresight, you would not accept the example I offered you. You would laugh, like the young Virginian laughed at Frances Trollope's concern for an enslaved girl. You would call me silly and sentimental and complain, like Ronny Heaslop, about my distracting you from doing justice. You would be completely sincere in your reaction. And it is not possible for you to be otherwise.

The key point of the Shameful Conclusion is that we are morally hopeless. Those future people, with their better moral judgment, will look back upon us and see what we cannot see. They will be astonished that we could live with ourselves, doing these terrible things we do. They will see that we are no better than slaveholders and colonialists. The most charitable among them will shake their heads and say, "well, what could they do? It was the time they lived in" and then move on. The rest will call us monsters.

\footnotetext{
${ }^{15}$ See Mills (1997) and the conception of hermeneutic injustice in Fricker (2007).
} 
Accepting the Shameful Conclusion means accepting this verdict of the future, without even knowing the evidence for its being rendered. It means accepting that we are indeed morally hopeless - that no matter how hard we try, how self-critical and reflective we might be, even if we somehow solve the known moral problems of racism and sexism and environmental destruction and global poverty - even then we will still be morally atrocious. It is not something we could possibly avoid.

So I reject the Shameful Conclusion. I do not believe that we are morally atrocious, at least not in this way. I do not accept the horror-stricken verdict of future people. This should also be your response, so long as you care about your current moral beliefs, and about the possibility of moral improvement in our actual world.

To see this, suppose you think that our world is already quite morally bad, in the ways I've mentioned. You cannot see any justification for the atrocious way we treat poor people, queer people, or non-human animals. You cannot tolerate our reckless destruction of the environment. You wish to see these moral atrocities undone - you want to improve our behavior. You are doing what you can, in your advocacy, in your philosophical work, in the way you talk to the people you care about. You can't be sure you will succeed, but at least you are making things a little better.

If the Shameful Conclusion is right, and if we are morally hopeless, then you should not be so sure of yourself. Why should you assume you are making things better? Ronny Heaslop, forceful imperialist, claimed to be making things better; he was bringing justice to a wretched country. The Shameful Conclusion implies that you are in no better position than Ronny Heaslop to know that you are making things better. What appears to you as justice may be nothing more than the self-perpetuation of an unjust system.

This is not idle philosophers' skepticism. The Shameful Conclusion tells us that at least some of our current behavior is atrocious in a way that we cannot recognize. The only thing we do not know is which. Which innocuous behavior or seemingly just institution will be unmasked by future better moral judges? Since we cannot know, why should you aim for moral improvement at all? Like Ronny Heaslop, you may be eroding the moral good even as you claim to be working to improve our world.

I am practically unable to abandon my belief in moral improvement - my belief that things would be better if we did something about poverty or discrimination. So I am unable to accept that we are morally hopeless, and therefore unable to accept the Shameful Conclusion. And since this is the only option left to us, now I reject Objectivity. ${ }^{16}$

\footnotetext{
${ }^{16}$ In effect, I abandon Objectivity for the same sort of reason that Sharon Street urges us to abandon moral realism (Street, 2006); I see Objectivity as entailing an implausible practical skepticism. According to Street, if realism is true, then we have no reason to trust our basic evaluative attitudes. According to me, if Objectivity is true, then we
} 


\section{Rejecting Objectivity}

Objectivity: There are objective moral truths that hold across all time.

When we take account of history, Objectivity is double-edged. It is what allows us to say that those people in the past, the slaveholders and colonialists, acted wrongly even though they lived in a different time, and according to different norms, than we do. It is what allows us to make a trans-historical criticism of moral norms. But then, on its other edge, Objectivity is what requires us to submit to the assessment of the better-judging moral future, and so come to doubt our own moral norms. Following Objectivity, it is very likely that we are justly cataloged with the slaveholders and colonialists, and no efforts to improve ourselves are likely to change this fact.

I try now to imagine those future people, looking back on my efforts to end racism or save the environment, and I imagine them shrugging at my unwitting moral atrociousness. And I imagine responding, easily and fluidly: future people, mind your own business! Your moral standards have no place here. You don't understand this world. How can you suggest that my sincere efforts to make things better are pointless or misguided? Who are you to say? Future people: take your Objectivity and shove it. ${ }^{17}$

What is left, if we abandon Objectivity? Perhaps the worst implications leap to mind first: absent Objectivity, we seem to be committed to saying that people in the past are not appropriately condemned for keeping to norms of their time. Slaveholders who did as slaveholders do are apparently in the moral clear. We can say that it is horrible to be a slaveholder now, but we have no right to extend this judgment into the past. And so forth - these are the costs of moral relativism.

I think that, with suitable amendment, we should accept these costs. Completely articulating a palatable concept of relativism is a project far greater than what can be attempted in the space remaining to me, so I shall say only a few things about how I think we ought to understand the idea.

This returns us to Bernard Williams, who famously defends a 'relativism of distance' in his Ethics and the Limits of Philosophy. For Williams, it is crucial that ethical reflection be focused upon genuinely possible ways that we might arrange our social world. By this he means

should doubt that we are capable of making moral improvements. Street and I agree that doubting our practical projects in this way is not coherent. We agree as well that if a grand metaethical thesis is to stand in the way of making sense of our moral lives, then it is the metaethics that must yield.

${ }^{17}$ That I am less polite about Objectivity is one way in which I differ from Ronald Dworkin. Another way is that I draw completely the opposite conclusion from reflecting on how firmly I am committed to my moral beliefs. Dworkin writes "[A]ny reason we think we have for abandoning a conviction is itself just another conviction, and ... we can do no better for any claim, including the most sophisticated skeptical argument or thesis, than to see whether, after the best thought we find appropriate, we think it so. If you can't help believing something, steadily and wholeheartedly, you'd better believe it." (Dworkin 1996, 118). I agree with all of this - and per my argument find that it tells against Objectivity. 
something far narrower than logical possibility or physical possibility; his point is that from a particular contingent starting point there are only so many ways that actual humans living in social systems can change while "retain[ing] their hold on reality, not engag[ing] in extensive self-deception, and so on". As a result, "Many outlooks that human beings have had are not real options for us now. The life of a Bronze Age chief or a medieval samurai are not real options for us: there is no way of taking on these outlooks." 18

Once we appreciate that social options are limited, we can recognize that not all instances of intertemporal moral difference have the same status. Williams says:

We should distinguish between real and notional confrontations. A real confrontation between two divergent outlooks occurs at a given time if there is a group of people for whom each of the outlooks is a real option. A notional confrontation, by contrast, occurs when some people know about two divergent outlooks, but at least one of those outlooks does not present a real option.

With that distinction to hand, we can get a grip on what it would mean to be relativists:

A relativist view of a given type of outlook can be understood as saying that for such outlooks it is only in real confrontations that the language of appraisal - good, bad, right, wrong, and so on - can be applied to them; in notional confrontations, this kind of appraisal is seen as inappropriate, and no judgments are made. (160)

The relativism of distance, then, is not the view that we must cast our eyes over great historical injustices and relativistically approve of each. We needn't say, for instance, 'it was perfectly fine, given the norms of their time, for the Virginia slaveholders to be as they were'. Rather, we should simply withhold judgment. ${ }^{19}$ Our confrontation with the outlook of early $19^{\text {th }}$ century slaveholders is not a real confrontation - their outlook is not a real option for us. The confrontation is notional, because we are not even considering living a life like theirs. The language of appraisal does not play the role here that it would, if slaveholding were anything like a real option to us. ${ }^{20}$ But slaveholding is not something we even admit into the set of morally possible options. Not being slaveholders is as unremarkable and unquestioned for us as being slaveholders was for them.

\footnotetext{
18 Williams 1985, 160-161). Further parenthetical citations are to this text.

${ }^{19}$ Richard Rorty makes a similar point about how best to interpret relativism, though he suggests that the most plausible form is better termed pragmatism. According to Rorty, "the pragmatist is not holding a positive theory that says that something is relative to something else. He is, instead, making the purely negative point that we should drop the traditional distinction between knowledge and opinion, construed as the distinction between truth as correspondence to reality and truth as a commendatory term for well-justified beliefs." (Rorty 1989, 170). ${ }^{20}$ Miranda Fricker argues that Williams has not provided an argument showing that the practical impossibility of such 'conversion' entails the inapplicability of moral evaluation (Fricker 2010). If Fricker is right, then the argument of this paper provides an independent route to the relativism of distance. Appraisal of temporally distant people is inappropriate not for the motivational reasons Williams suggests, but because that is the cost of rejecting Objectivity and escaping the Argument for Our Utter Moral Failure.
} 
The natural objection now is this: Appropriate or not, we want to be able to conclude that horrible people of the past were indeed horrible. It is perfectly natural for us to say that slaveholders and colonialists behaved in a morally atrocious way, and a relativism that requires us to abandon this belief as reflecting a merely notional confrontation - an 'inappropriate' application of evaluative language - does not do justice to the strength of our condemnation of these past people.

One answer to this objection is simply to rehearse what has already been said about Objectivity. Relativism is double-edged in a precise inversion of Objectivity. Just as affirming Objectivity allowed us to condemn the past and left us vulnerable to the condemnation of the future, affirming relativism allows us to evade future condemnation and unable to condemn the past. This is in the nature of things: if there are timeless moral truths, they are just as likely to tell against us as for us. Relativism allows us to affirm the truths of our time at the cost of being silent about others.

But I think we can say something more in reply to this objection, something hopefully less frustrating. There is a way in which it makes sense for us to condemn historical wrongs, even for relativists. Williams alludes to this in the following passage:

If we are to take seriously the relativistic suspension of ethical judgment, we have to conceive of the society in question as a whole. There are some ethical concepts that we can apply to people and their actions - virtue and vice concepts, for instance - even when the outlook of the society in which they lived is not in real confrontation with ours. This involves taking the people in abstraction from the social practices in which they lived, and so, often, we do not see them realistically. (162, emphases added)

It is not entirely clear what Williams is saying here. Is he simply saying that we do sometimes try to morally evaluate historical persons out of their social context, resulting in confused and unrealistic assessment? Or is he saying that this sort of imaginative abstraction from circumstances somehow allows the language of appraisal to become appropriate once again, despite our relativism?

I am not certain what Williams' view is in the end. But here is mine: when we engage in this sort of decontextualizing evaluation, we are applying our moral judgments sensibly. But we are not applying them in the same way as when we evaluate real moral options. In imaginatively plucking a person from her historical context, we are transforming her from a real person into an abstract space of practical possibilities. We are trying to draw out of her circumstances those features that seem relevant to our own, even if they do not and could not mean entirely the same thing for us that they did in the past. When we condemn those Virginian slaveholders in Frances Trollope's account, we are not really judging them - we are judging the features of their situation that bear resemblance to our present-day world. It is not that enslaving is an option for us. But what $i s$ an option for us is ignoring the pain of a child, or not caring for a person because others regard her as less than human, or treating another rational being with malign indifference. These 
choices, abstracted in this way, remain real options for us. The language of evaluation serves to commit us to how we might respond to these options, and its application to people in the past is simply an indirect and abstracted way of accomplishing this, much as we might use moral evaluation of characters in highly unreal science fiction to think through the implications of our real practices. ${ }^{21}$

When we release past people from our imaginative abstraction and deposit them back into the full reality of their social circumstances, we lose an intelligible grasp on morally evaluating them. That is the truth of epoch relativism. But this is consistent with our using reflection on historical wrong as a vehicle for interrogating similar features of our own present. That explains why we continue to insist upon applying moral evaluation to the past.

And it also explains, finally, what the people in the future will think about us. They will imaginatively lift us from our social context, just as we do to people of the past. In their minds we will be spun, individualized yet abstracted, deconstructed in pursuit of the similarities that will allow their condemnation of us to coordinate their own moral options. They will call us morally atrocious, but when they do this, it is not really $u s$ they are judging. They are judging abstractions of us, logical silhouettes seen from great distance. Their judgment does not apply to the actual us, to our real lives in present social context.

Whatever they say, we are not utterly morally atrocious. We are certainly not perfect, indeed we are quite bad. But there is still hope for us. ${ }^{22}$

\section{References}

Breen, J., ed. (1996). Women Romantics 1785-1832: Writings in Prose. London: JM Dent.

Copp, D. (1995). Morality, Normativity, and Society. Oxford: Oxford University Press.

Dworkin R.. (1996). Objectivity and Truth: You'd Better Believe It. Philosophy and Public Affairs 25(2), pp. 87-139.

Forster E.M. (1924). A Passage to India. New York: Harcourt.

Fricker, M. (2007). Epistemic Injustice: Power and the Ethics of Knowing. Oxford: Oxford University Press.

Fricker, M. (2010). The Relativism of Blame and Williams's Relativism of Distance. Proceedings of the Aristotelian Society Supplementary Volume LXXXIV, pp. 151-177.

Fukuzawa, Y. (1899/1966). The Autobiography of Yukichi Fukuzawa. Trans. Eiichi Kiyooka. New York: Shocken Books.

\footnotetext{
${ }^{21}$ This idea has something in common with Allan Gibbard's suggestion that moral judgments about others in unfamiliar circumstances express plans for our actions were we to find ourselves similarly situated (Gibbard 2003). I have some difficulty with the use of the word 'plan' here, but like Gibbard I do find it intelligible that our judgments of distant others are really mostly about ourselves.

22 Great thanks for feedback on this chapter to Nomy Arpaly, Sophie-Grace Chappell, Geraldine Ng, Sara Protasi, Nicholas Smyth, Amia Srinivasan, and audience members at the '30 Years of Bernard Williams' Ethics and the Limits of Philosophy' conference held at Oxford in 2015.
} 
Gibbard, A. (2003). Thinking How to Live. Cambridge MA: Harvard University Press.

Gessen, M. (2017). The Future is History: How Totalitarianism Reclaimed Russia. New York: Penguin. Huemer, M. (2016). A liberal realist answer to debunking skeptics: The empirical case for realism.

Philosophical Studies 173(7), pp. 1983-2010.

Isaac, B. (2004). The Invention of Racism in Classical Antiquity. Princeton: Princeton University Press

Korsgaard, C.M. (1996). The Sources of Normativity. Cambridge MA: Harvard University Press

Mills, C.W. (1997). The Racial Contract. Ithaca: Cornell University Press.

Moody-Adams, M.M. (1999). The Idea of Moral Progress. Metaphilosophy 30(3), pp. 168-185.

Moody-Adams, M.M. (2017). Moral Progress and Human Agency. Ethical Theory and Moral Practice

20(1), pp. 153-168.

Pinker, S. (2018). Enlightenment Now: The Case for Reason, Science, Humanism and Progress. New York: Viking.

Rorty, R. (1989). Solidarity or Objectivity? In: M. Krausz, Relativism: Interpretation and Confrontation. Notre Dame: University of Notre Dame Press, pp. 167-183.

Scheffler, S. (2013). Death and the Afterlife. Oxford: Oxford University Press.

Street, S. (2006). A Darwinian Dilemma for Realist Theories of Value. Philosophical Studies 127(1), pp. 109-166.

Thorlby, A.K., ed. and trans. (1966). The Romantic Movement. London: Longmans Green \& Co.

Williams, B. (1985). Ethics and the Limits and Philosophy. Cambridge MA: Harvard University Press.

Williams, B. (2005). In The Beginning Was the Deed: Realism and Moralism in Political Argument.

Edited by G. Hawthorne. Princeton: Princeton University Press.

Williams, E.G. (2015). The Possibility of an Ongoing Moral Catastrophe. Ethical Theory and Moral Practice 18(5), pp. 971-982.

Wilson, C. (2010). Moral Progress Without Moral Realism. Philosophical Papers 39(1), pp. 97-116.

Wong, D.B. (2006). Natural Moralities: A Defense of Pluralistic Relativism. Oxford: Oxford University Press. 